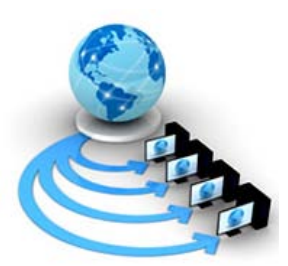

Volume 8, No. 9, November-December 2017

International Journal of Advanced Research in Computer Science

RESEARCH PAPER

Available Online at www.ijarcs.info

\title{
A NOVEL APPROACH TO ANALYSIS DISTRICT LEVEL LONG SCALE SEASONAL FORECASTING OF MONSOON RAINFALL IN ANDHRA PRADESH AND TELANGANA
}

\author{
P. Chandrashaker Reddy \\ Research Scholar, JNTUA, \\ Ananthapuramu, AP, INDIA.
}

\author{
Dr. A. Suresh Babu \\ Associate Professor of CSE Dept.JNTUA, \\ Anathapuramu, AP, INDIA.
}

\begin{abstract}
India is a nation which purely relies on agriculture, so rainfall prediction is very important for agriculture to make crop management decisions. Long scale forecast of rainfall during monsoon season (southwest and northeast), at the spatial firmness of a district, could serve as a significant comment to the agricultural community to take better decisions in yield management. Such forecasts are not producing efficient results which are available now. In this paper rainfall, crops and soil data of Andhra Pradesh (AP) \& Telangana (TS) states are gathered to analyze rainfall patterns based on soil for crop management. Variety of crops needs adequate rainfall based on their different categories. In this paper, we are proposing a model which relates the analysis of rainfall patterns, soil types and several crops grown in two states on seasonal wise. We are experimenting with last 12 years of rainfall data, a variety of crops grown in different seasons and identifying the average rainfall needed for distinct of crop types. DBSCAN clustering algorithm used to determine the rainfall patterns as low and high density. The proposed system serves as a tool to explore the rainfall patterns. The statistical results show that proposed model could enhance those effectiveness and exactness.
\end{abstract}

Keywords: Rainfall; DBSCAN ; Crop; Forecast; SWM; NEM; Soil; Clustering ;AP \& TS

\section{INTRODUCTION}

Determination of climate features is most important for the success or the failure of agricultural decisions. It is a fact that production of food strongly depends on climate changes; it will show details of humidity, temperature, wind and rainfall for the current day and the forecast for the next five days [1], In addition, a farmer will also be provides with the extreme weather alerts like hailstorms or unseasonal rains. Rainfall is very significant and essential for agricultural depended countries like India because over $50 \%$ of rural households depends on agriculture as their principal means of livelihood. The factory farm sphere of India has occupied almost 43 percent of India's geographical area.

Usually, agriculturists utilised traditional methods to anticipate the rain based on their perception of such marvels the formation of halo around the moon, wind and cloud movement, lightning, animal behavior, bird movement etc. Later on, those customary strategies joined with logical perceptions that can end up being preferable in determining climate over depending on single strategy. As existing, operational long scale forecasting of rainfall in SWM are publicize by IMD (India Meteorological Department) for an entire country and four broad regions of India [6]. Every broad consist of 8-10 meteorological subdivisions out of 36 . Operational LRF of SWM rainfall is not yet available to users at the spatial resolution of a meteorological subdivision/cluster of districts/district. Using a proposed technique, LRF of SWM \&NEM rainfall for subdivisions wise were being given since 1990, depended on this new method, has accomplished in delivering better forecasts for all subdivisions for the past 26 years, as well forecast for the nation as a whole.
AP\&TS jointly have 23 districts; agriculture in these states principally depends on rain-fed water sources for irrigation. In AP and TS $71 \%$ of people are dependent on agriculture and its partnered segments, altogether geological zone $42 \%$ of the land is utilized for cultivation in the two states (total 27.44 Million Hectors, 12.754 Million Hectors in agriculture)[5,4]. It is evaluated that about 65 percent of the cultivated space falls under dryland agriculture while the rest is irrigated. This area is drought prone to erratic rainfall received during crop season; this requires precise rainfall forecast framework for farmers to take decisions on crop management system.

\section{A. Agro - Climates Zones in AP \& TS}

This section describes the various zones (parts), required average rainfall for cultivation, different type's soils and variety of crops grown in those zones. Combined Andhra Pradesh is the fifth largest state in India with a geographical area of $27.44 \mathrm{~m}$ ha. Several primary yields are grown on its soils. These States(23 districts) have been divides into seven agro-climatic zones (viz., Krishna-Godavari, North Coastal, Southern, Northern Telangana, Southern Telangana, Scarce Rainfall and High altitude and Tribal). These seven zones of AP \& TS states geographically shown as in Figure 1 . The reach for precipitation regularly received, land sorts existing, soils happening and significant yields, cropping frameworks developed in these zones are outfitting in Table 1 


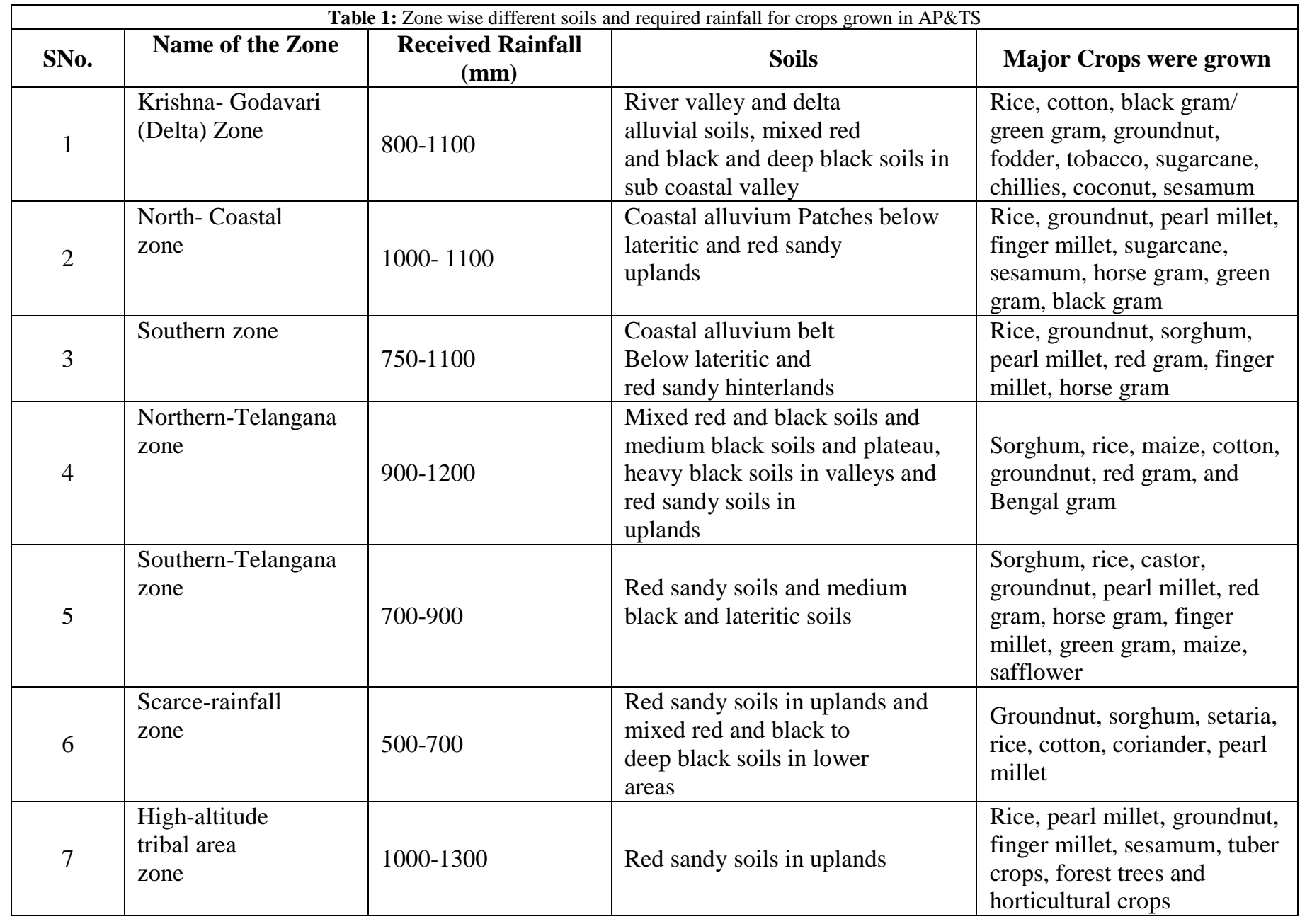

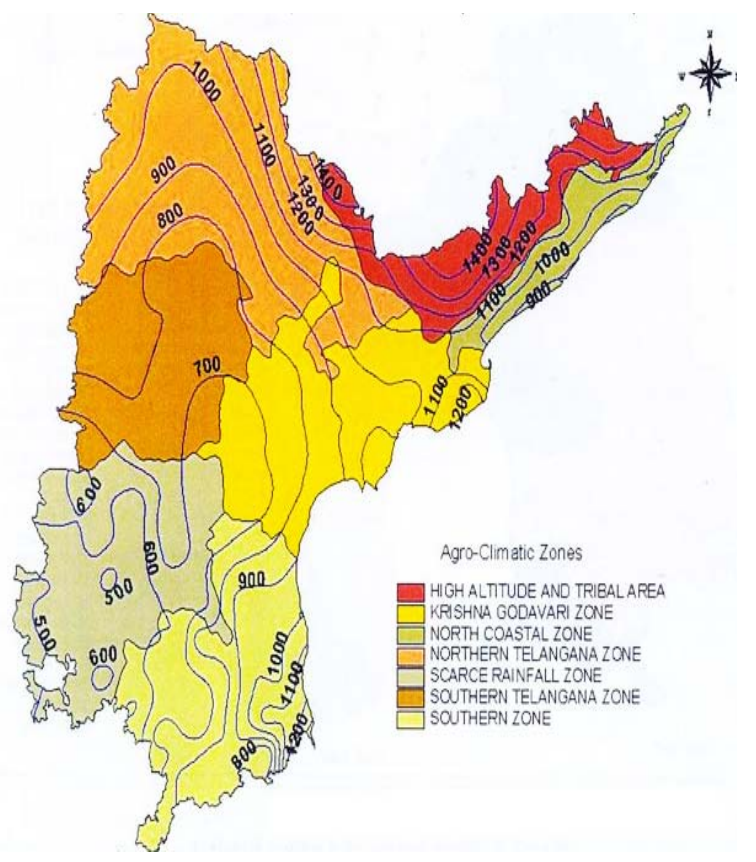

Figure 1: Agro-Climate Zones of AP\&TS states

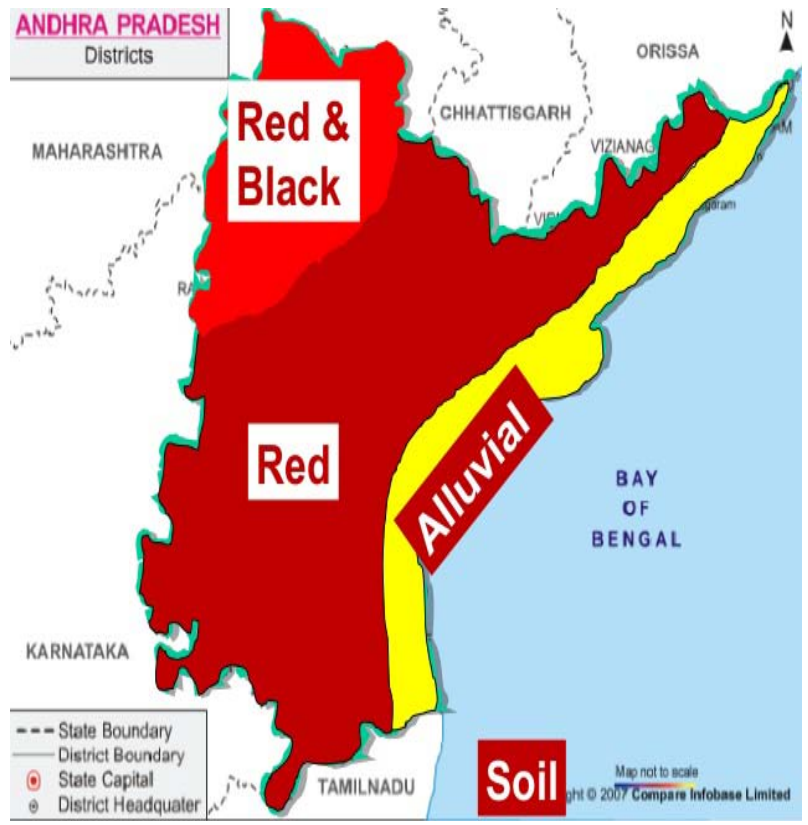

Figure 2: Soil Map of AP \& TS states 


\begin{tabular}{|c|l|l|}
\hline \multicolumn{2}{|c|}{ Table 2: soil types exist in district wise and various crops were grown in different soils } \\
\hline Soil Type & \multicolumn{1}{|c|}{ Places (Districts) of occurrence } & \multicolumn{1}{c|}{ Major Crops } \\
\hline Red soils & $\begin{array}{l}\text { Parts of Ranga Reddy, Medak, Guntur, Prakasam, } \\
\text { Nellore and Kurnool }\end{array}$ & $\begin{array}{l}\text { Groundnut, sorghum, pearl millet, foxtail } \\
\text { millet, red gram, green gram, cowpea, } \\
\text { castor and horse gram }\end{array}$ \\
\hline Laterites & $\begin{array}{l}\text { Kavali taluk of Nellore, Zaheerabad Mandal of Medak } \\
\text { and very small pockets in Visakhapatnam, Srikakulam } \\
\text { and West Godavari }\end{array}$ & Mango, Cashew and Tamarind trees \\
\hline Black soils & $\begin{array}{l}\text { Parts of Adilabad, Nizamabad, Karimnagar, } \\
\text { Warangal, Khammam, Medak, Ranga Reddy, } \\
\text { Mahabubnagar, Kurnool, Anantapur, Nellore and } \\
\text { Guntur }\end{array}$ & $\begin{array}{l}\text { Cotto, chillies, sunflower, Bengal gram, } \\
\text { sorghum, safflower and coriander }\end{array}$ \\
\hline Alluviums Soils & Parts of East and West Godavari, Krishna and Guntur & $\begin{array}{l}\text { Rice, Sugar-cane, Plantain, Guava, Lemon } \\
\text { and Oranges. }\end{array}$ \\
\hline
\end{tabular}

\section{B. Soils types}

Due to various forms of mineral and organic compositions, there are different types of soil that undergo different environmental pressures. Mainly four types of soils exist in these two states where they are Red, Laterites, Black and Alluviums soils. Soil map of these states shown in figure 2. Variety of soils, places of their occurrence and crops are grown soils are discussed in Table 2.

\section{Crops types}

Crops can be divided into four main categories depending on their usage. There are Food Grains (Rice, Wheat, Maize, Millets and pulses), cash crops (cotton, jute Sugarcane, Tobacco and oilseeds), plantation crops (Tea, coffee, coconut and rubber) and horticulture crops (fruits and Vegetables). These are geographically represented in Fig. 3. Rice covers about one-third of the total cultivated area of the state; it is also cultivated in rabi season with the use of irrigation. Jowar, Bajra and Ragi are grown in large areas, but unfortunately area under these crops has drastically decreased over the years. Locally crop season is classified as Kharif (June/JulySept/Oct), Rabi (Nov/Dec -April/May) and Ziad (summer)[2,3]. Different crops grown in two states seasonal wise and required weather conditions summarized in Table 3.

\section{Rainfall}

Agricultural production in AP\&TS at most depends upon the distribution of rainfall. The high amount of rainfall in the beginning and sunny/ dry weather at the time of ripening is very helpful for a good crop. AP acquires maximum rainfall during SWM (Southwest Monsoon) (Jun-Sept) as well as NEM (Northeast Monsoon) (Oct-Dec). SWM offers 69\% (925 $\mathrm{mm}$ ) of rainfall in the total of AP and NEM offers 22\% (300 $\mathrm{mm}$ ) of rainfall in the total of AP and remaining contributed by during winter and a hot period is shows in Fig. 4. Information on probable rendering of SWM \& NEM could show to be important in farming plan, agriculture activities and management of rain water [13]. This type of forecast is very useful for agriculturists as an input, like fertilizers, seeds, etc.

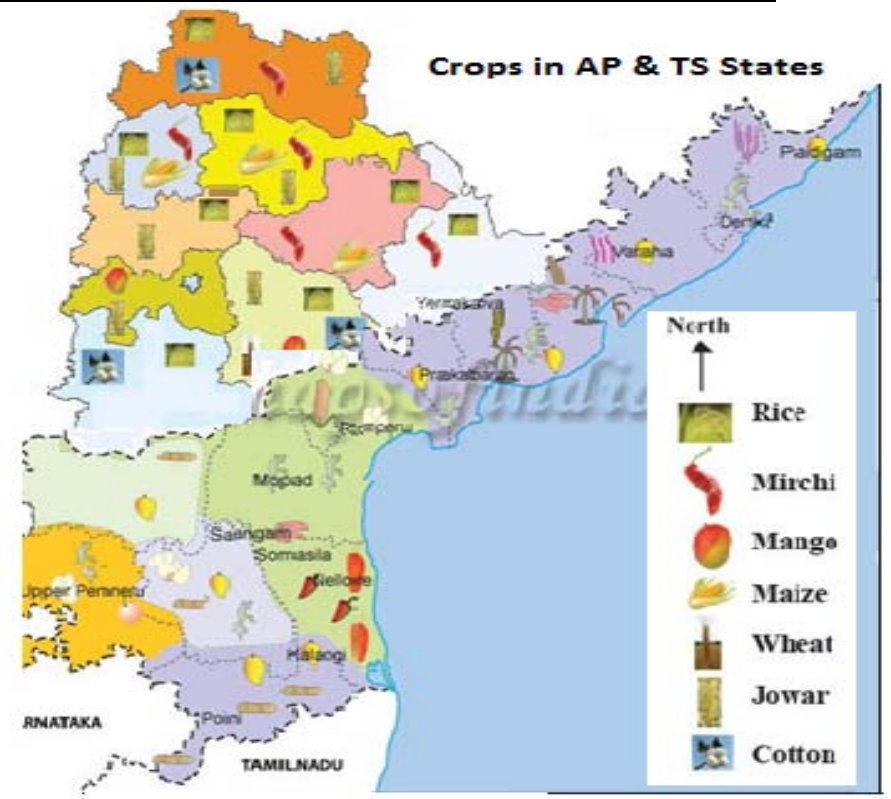

Figure 3: District wise Crop Map of AP\& TS States.

\section{Monsoonwise Rainfall in Andhra Pradesh}

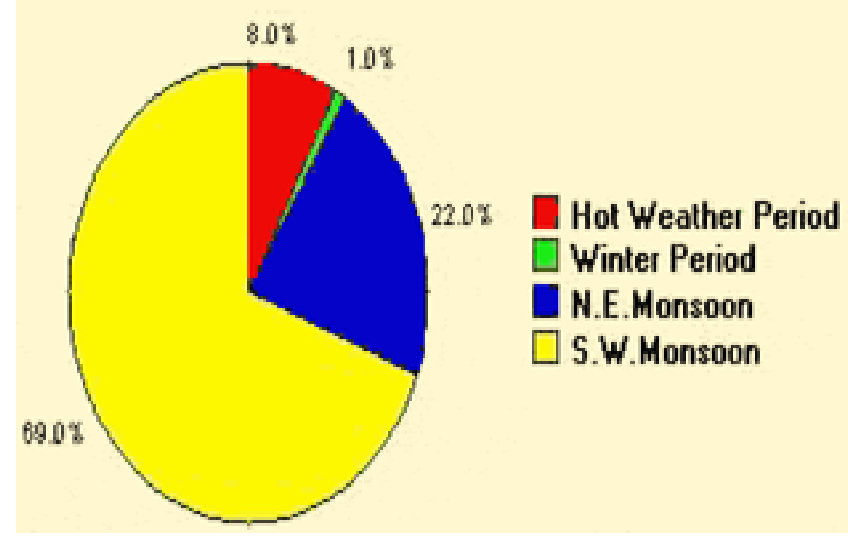

Figure 4: Avg. rainfall percentage monsoon wise in AP\&TS 


\begin{tabular}{|c|c|c|c|c|c|c|}
\hline \multicolumn{7}{|c|}{ Table 3: Variety of crops and their required weather conditions to grown in AP \& TS } \\
\hline Crop Name & $\begin{array}{c}\text { Area in } \\
\text { Hectors(Lakh) }\end{array}$ & $\begin{array}{c}\text { Soil } \\
\text { Supported }\end{array}$ & Season & Rainfall need(mm) & $\begin{array}{l}\text { Avg. Temp. } \\
\left.\text { Needed ( }{ }^{0} \mathrm{C}\right)\end{array}$ & Remarks \\
\hline Rice & 40.96 & $\begin{array}{c}\text { deep clayey } \\
\text { and loamy soil }\end{array}$ & Kharif & 150 to 300 & $22-32$ & \\
\hline Rice & 3.19 & \multirow{5}{*}{$\begin{array}{c}\text { Inferior } \\
\text { alluvial or } \\
\text { loamy soil. }\end{array}$} & \multirow{5}{*}{ Kharif and Rabi } & \multirow{5}{*}{50 to 100} & \multirow{5}{*}{$27-32$} & \\
\hline Jowar & 7.63 & & & & & \\
\hline Maize & 0.56 & & & & & \\
\hline Bajra & 0.43 & & & & & \\
\hline Ragi & 3.19 & & & & & \\
\hline Wheat & 0.10 & $\begin{array}{l}\text { fertile loamy } \\
\text { and clayey } \\
\text { loamy soil }\end{array}$ & Rabi & 75 to 100 & $\begin{array}{l}10-15 \\
21-26\end{array}$ & $\begin{array}{c}\text { sowing } \\
\text { harvesting }\end{array}$ \\
\hline Redgram & 5.50 & \multirow{4}{*}{ loamy soils } & \multirow{4}{*}{ Rabi } & \multirow{4}{*}{$40-45$} & \multirow{4}{*}{$20-25$} & \\
\hline Greengram & 3.42 & & & & & \\
\hline Blackgram & 4.46 & & & & & \\
\hline Bengalgram & 6.15 & & & & & \\
\hline Groundnut & 14.61 & $\begin{array}{l}\text { Red and Black } \\
\text { Soils }\end{array}$ & kharif & $50-75$ & $20-30$ & \\
\hline Castor & 1.68 & $\begin{array}{l}\text { Red and light } \\
\text { alluvial soils }\end{array}$ & Khariff & $50-75$ & $20-25$ & \\
\hline Sunflower & 2.88 & Black soil & kharif and rabi & $52-75$ & $55-80$ & \\
\hline Soybean & 1.42 & Black soil & Kharif & $50-90$ & $57-85$ & \\
\hline Cotton & 16.21 & Black soil & kharif & $50-100$ & $21-30$ & \\
\hline Sugarcane & 1.75 & $\begin{array}{l}\text { deep rich } \\
\text { loamy soil }\end{array}$ & Kharif & $75-150$ & $21-27$ & \\
\hline Chilli & 1.96 & $\begin{array}{c}\text { Sandy and clay } \\
\text { loamy soil }\end{array}$ & kharif and rabi & $40-90$ & $20-25$ & \\
\hline Tobacco & 1.51 & $\begin{array}{c}\text { alluvial soils, } \\
\text { black clayey or } \\
\text { loamy soils }\end{array}$ & kharif and rabi & $50-100$ & $15-20$ & \\
\hline Jute & - & $\begin{array}{l}\text { Light sandy or } \\
\text { clayey soils }\end{array}$ & kharif & $120-150$ & $70-100$ & \\
\hline
\end{tabular}

\section{RELATED WORK}

In this section, we discussed about recent related work done around the globe. Kipkorir E.C, et al. [1] proposed the model for climate analysis of Baringo District which is located in Kenya and authors discussed about how the weather is changed according to the different seasons and they summarized the season wise rainfall in that district of past 20 years from 1980 to 2000. O Prasad, et al. [2] proposed a method of long range Forecast (LRF) in seasonal level rainfall as district during the south monsoon of Vayu Mandal and them taken 12 days of rainfall data for prediction purpose.

A.Ramakrishna, et al. [3] submitted work on periodical analysis of rainfall patterns of Nira Basin and they proposed a model for forecasting of rainfall. Authors consider of 2-8 years of data after 1960's and they used a wave let analysis, it produces accuracy results compared to existing methods. P. Guhathakurta, et al. [11] analyzed extreme rainfall patterns in Andhra Pradesh where monsoon and post-monsoon seasons. For this study, they consider more than 70 years of data 19012000 of 155 substations in AP.

Vijaya Kumar, et al. [6] presented work on long term rainfall trends in India and they consider 135 years (1871-2005) of 30 subdivision of India. Authors concluded as monsoon months (June-Sept.) have received $80 \%$ of annual rainfall. J Nagendra Kumar, et al. [10] proposed GIS-MAP model for spatial analysis of rainfall data of Andhra Pradesh and Telangana states using R. They summarized data as district wise and compared with existing methods. O Prasad, et al. [12] reviewed the district level long scale rain forecast during southwest monsoon in Andhra Pradesh. They identified as the maximum of annual rainfall is getting in SWM, NEM.

\section{DATA USED AND METHOD OF ANALYSIS}

District wise rainfall data during SWM, NEM season for a period of 12 years (2004-16) have been considering for this study, this data is collected from IMD (India Metrological Department). Clustering equations are developed between rainfall data and different seasons using DBSCAN algorithm and Cluster Dendrogram method by using R-Studio for 12 years (2004-16) data. Long Period Average (LPA) of monthly, seasonal and annual rainfall dataset for the districts of AP \& TS is shown in Annexure A.

\section{RESULTS AND DISCUSSIONS}

The dataset contains the rainfall values for past 12 years (2004-16) in district level that are representing in seasonal wise (SWM, NEM), the data file in figure 5. First, we normalized the data for easy representation then applied the clustering methods (DBSCAN and Hierarchical) to identify the rainfall patterns using R-Tool. Plot the graphs to identify the rainfall patterns of past 12 years in SWM, NEM using DBSCAN Algorithm and identify the all season's rainfall patterns by using Hierarchical clustering model. Dataset 
contains total 274 instances and it divided into three clusters. 241 instances fall in to cluster one, it represents regular rainfall patterns of districts in southwest monsoon season, and 31 instances fall into cluster two it represents 20-30 percent fewer rainfall patterns and four instances distributed into cluster 3 as represents extreme less rainfall patterns. These three cluster objects represented in different color codes in fig.5a for SWM, $5 \mathrm{~b}$ for NEM.

Comparison graph of rainfall received in SWM and NEM of AP\& TS states shown in Fig. 6 as years wise (2004-16). The analysis shows that max of rainfall received during the period of SWM \& NEM, so this is period is very important for agriculture to make their own crop decisions. Agriculture field is requires better prediction system for analysis of weather conditions during June to December months.

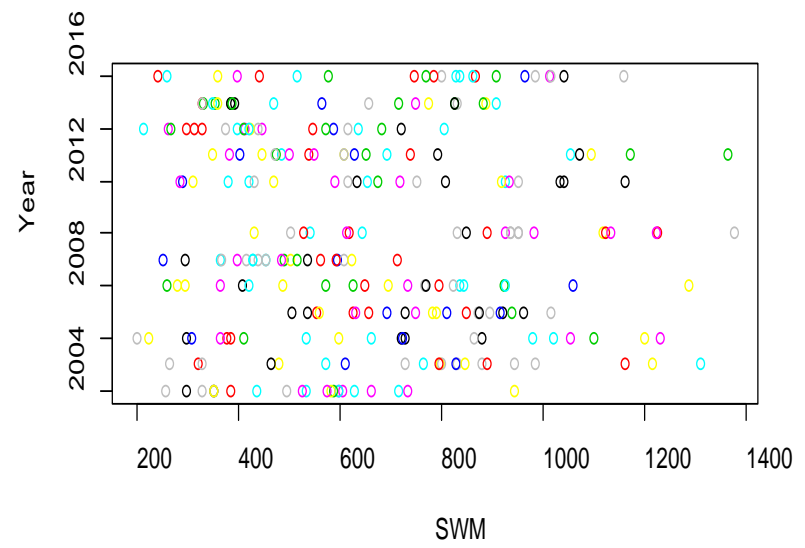

Figure 5a: Rainfall patterns in Southwest Monsoon

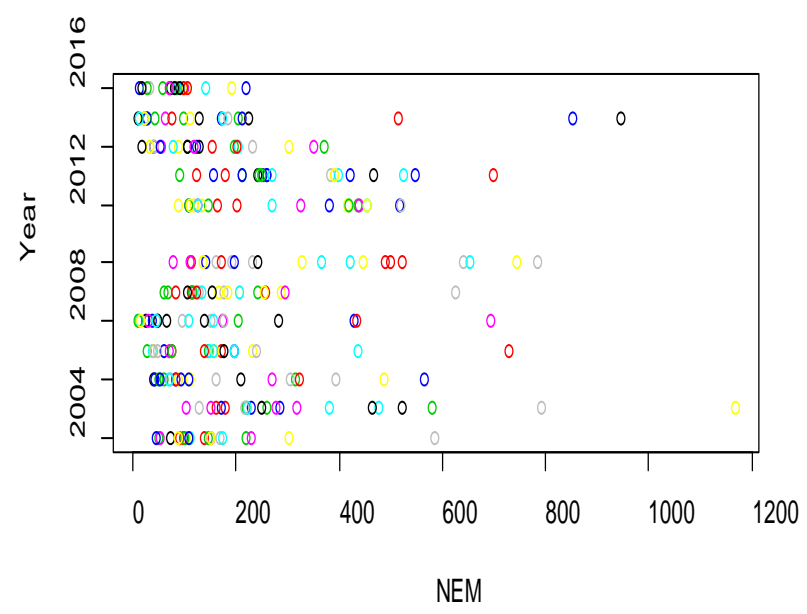

Figure. 5b: Rainfall patterns in Northeast Monsoon

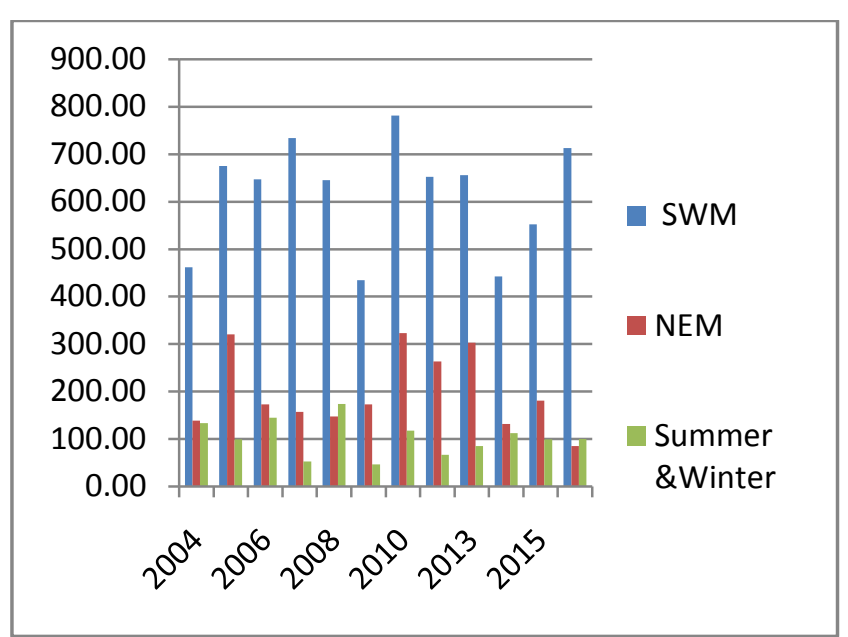

Figure 6: Seasonal Rainfall comparison in different years

\section{CONCLUSION}

In traditional methods, rainfall forecast is challenging task and we cannot get accuracy results. In this proposed a novel approach to predict the long scale rainfall patterns of AP \& TS states district level. It is efficient and accurate to compare with community models and it is producing better results. DBSCAN algorithm is used to identify the rainfall patterns as density wise (high, low) for long term forecast by using past 12 years data of AP \&TS district level. These types of new technology is used for large scale rainfall forecasting data analysis has the potential to better enhancement the weather prediction too.

\section{ACKNOWLEDGMENT}

Maps showing the districts of Andhra Pradesh \& Telangana, soil diagram and crops diagrams are downloaded from the website WWW.MAPINDIA.COM and rainfall data of district wise of two states made available by Additional Director General of Meteorology (Research), India Meteorological Department, Pune.

\section{REFERENCES}

[1] Kipkorir E.C. et al. , "Analysis of rainfall climate on the Njemps Flats, Baringo District, Kenya,” Journal of Arid Environments, vol. 50, no. 3, pp. 445-458, 2002.

[2] O Prasad et al . "District level long range forecast of seasonal rainfall during southwest monsoon, Vayu Mandal” , v.34, no.1-2, pp: 51-56.

[3] A.Ramakrishna et al. , "Trend and Periodicity Analysis in Rainfall Pattern of Nira Basin”, Central India American Journal of Climate Change, 2014

[4] Basistha et al., "An Analysis of Historical Rainfall Change in Indian Himalayas”, International Journal of Climatology, 2008.

[5] Murumkar et al., "Seasonal and Annual Variations of Rainfall Pattern in the Jamuneswari Basin, Bangladesh", On a Sustainable Future of the Earth's Natural Resources (ed.). Springer Earth System Sciences, Springer-Verlag, Berlin, Heidelberg,. 2013.

[6] Kumar et al., "Analysis of Long-Term Rainfall Trends in India”, Hydrological Sciences Journal, 55, 484-496. 2010

[7] Jagannathan et al. "Trends and Periodicities of Rainfall over India” , Monthly Weather Review, 101, 371-375. http://dx.doi.org/10.1175/1520 0493. 
[8] Raghavendra et al "Trends and Periodicities of Rainfall in Sub-Divisions of Maharashtra State” , Indian Journal of Meteorology and Geophysics, 25, 197-210.

[9] Kumar, et al., "Trends in Seasonal and Annual Rainfall and Rainy Days in Kashmir Valley in the Last Century" . Quaternary International, 212, 64-69.

[10] J Nagendra kumar et al., "GIS-MAP based Spatial Analysis of Rainfall Data of Andhra Pradesh and Telangana States using R”, International Journal of Computer and Engineering.

[11] P. Guhathakurta et al., "Extreme rainfall analysis of AP using a probability didsbution model : A regional estimate"
MAUSAM, 56, 4 (October 2005), 785-794, 551.577.21 : 551.507.777 (548.23)

[12] O Prasad et al., "District level long range forecast of rainfall during southwest monsoon in Andhra Pradesh", J.india Geo Physics Union.

[13] P Chandrashaker Reddy et al., "Survey On Weather Prediction Using Big Data Analystics", Second IEEE International Conference On Electrical, Computer And Communication Technologies (ICECCT- 2017).

\begin{tabular}{|c|c|c|c|c|c|c|c|c|c|c|c|c|c|}
\hline \multicolumn{14}{|c|}{ Annexure A : Monsoon wise rainfall data of 23 Districts of AP\&TS states (2004-2016) } \\
\hline Dist. & an & Feb & Mar & April & May & June & July & Aug & Sept & Oct & Nov & Dec & nnual \\
\hline & \multicolumn{2}{|c|}{ Winter } & \multicolumn{3}{|c|}{ Summer } & \multicolumn{4}{|c|}{ South-West monsoon } & \multicolumn{3}{|c|}{ North-East monsoon } & \\
\hline Khan & 6.42 & 6.95 & 5.86 & 22.83 & 4 & 63 & 300.40 & 294.40 & .64 & 103.10 & 178.87 & 3.58 & 99.82 \\
\hline Krishna & 10.62 & 13.53 & 13.29 & 15.75 & 71.18 & 150.66 & 190.95 & 196.38 & 90.62 & 173.06 & 181.84 & 9.42 & 1217.30 \\
\hline Kurnool & 92 & 2.81 & 14.62 & 20.55 & 50.62 & .88 & 109.21 & 115.15 & 159.34 & .20 & 124.27 & 2.01 & 788.59 \\
\hline Medak & 7.48 & 7.92 & 32.38 & 18.53 & 28.16 & 96.80 & 200.43 & 159.74 & 192.13 & 69.99 & 131.06 & 0.92 & 945.56 \\
\hline Nellore & 04 & .01 & 11.40 & 15.24 & 52.78 & 56.62 & 80.25 & 102.82 & 91.71 & 232.03 & 161.87 & 100.84 & 924.60 \\
\hline Nizamabad & 8.62 & 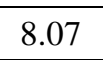 & 27.38 & 20.86 & 20.64 & 133.76 & 254.46 & 210.80 & 198.65 & 66.73 & 132.69 & 0.87 & 1083.54 \\
\hline Prakasam & 6.44 & 12.41 & 15.38 & 17.68 & 58.11 & 73.44 & 89.51 & 102.47 & 126.25 & 172.69 & 149.47 & 21.03 & 844.89 \\
\hline Ranga Reddy & 4.06 & & 23.42 & 30 & & 102.79 & 156.97 & 176.90 & 175.76 & 77.98 & 126.87 & 0.82 & 924.03 \\
\hline Srikakulam & 7.56 & 7.55 & 15.77 & 28.68 & 87.02 & 156.35 & 198.01 & 188.21 & 238.32 & 196.71 & 217.51 & 11.76 & 1353.45 \\
\hline Vishakhapatnam & 4.87 & 10.66 & 16.53 & 41.61 & 75.31 & 159.15 & 151.28 & 170.14 & 230.10 & 197.82 & 213.96 & 13.99 & 1285.41 \\
\hline Vizaya Nagaram & 14.34 & 6. & 16.81 & 30 & & & 181 & 195.72 & & 168.24 & 198.09 & 10.78 & 1313.59 \\
\hline Warangal & 5.46 & 6.85 & 24.81 & 19.56 & 31.43 & 158.21 & 268.21 & 238.20 & 228.96 & 83.48 & 156.22 & 1.96 & 1223.35 \\
\hline West Godaval & 4.45 & 7.61 & 8.16 & 12.33 & 62.54 & 149.55 & 208.69 & 223.77 & 219.81 & 161.40 & 190.60 & 10.03 & 1258.94 \\
\hline Adilabad & 12.59 & 6.31 & 24.34 & 13.94 & 19.79 & 158.43 & 313.32 & 237.47 & 214.49 & 68.90 & 141.70 & 1.22 & 1212.49 \\
\hline Ananthapur & 3.86 & 3.28 & 14.68 & 27.63 & 68.87 & 64.66 & 68.13 & 82.06 & 129.02 & 87.66 & 108.34 & 5.68 & 663.89 \\
\hline Chittor & 2.82 & 7.12 & 14.12 & 29.68 & 80.34 & 83.36 & 96.78 & 113.78 & 126.42 & 155.88 & 141.15 & 74.68 & 926.12 \\
\hline Cuddapah & 1.99 & 5.70 & 9.30 & 19.08 & 44.24 & 72.72 & 86.01 & 100.16 & 116.59 & 105.72 & 111.16 & 25.27 & 697.94 \\
\hline East Godavaru & 2.05 & 6.52 & 9.41 & 24.37 & 66.67 & 144.36 & 192.96 & 183.14 & 219.06 & 182.92 & 200.99 & 11.22 & 1243.68 \\
\hline Guntoor & 7.70 & 12.80 & 10.78 & 13.07 & 56.65 & 113.26 & 148.16 & 157.70 & 183.30 & 143.88 & 163.59 & 10.58 & 1021.48 \\
\hline Hyderabad & 6.61 & 8.29 & 25.32 & 32.30 & 35.32 & 102.73 & 177.16 & 175.54 & 195.41 & 84.65 & 140.03 & 1.51 & 984.86 \\
\hline Karim Nager & 15.43 & 9.59 & 33.61 & 21.13 & 27.98 & 140.39 & 273.58 & 225.59 & 237.60 & 84.37 & 160.99 & 1.27 & 1231.52 \\
\hline Mahabub Nager & 2.01 & 2.50 & 17.89 & 23.31 & 31.26 & 87.62 & 121.45 & 129.11 & 165.60 & 91.49 & 128.55 & 1.60 & 802.39 \\
\hline Nalgonda & 7.52 & 9.66 & 2.84 & 17.14 & 40.38 & 110.68 & 118.44 & 157.76 & 175.14 & 124.06 & 149.60 & 0.64 & 913.86 \\
\hline
\end{tabular}

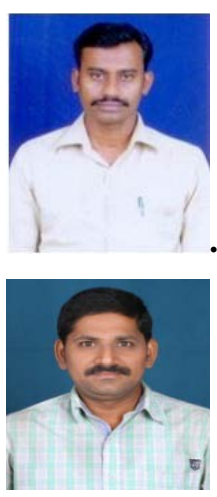

Dr. A.Suresh Babu received B.Tech and M.Tech degree in Computer Science and Engineering form JNTUA, Anathapur and Ph,D Degree is received from JNTUA, Ananthapur. He is working as Assocaite Professor of CSE Dept. and Additional Controller of Examinations in JNTU University, Ananathpur. His research focus on Big data, Networks, IoT and Data mining.

P. Chandrashaker Reddy received B.Tech and M.Tech degree in Computer Science and Engineering form JNTUH. At present working as research scholar of JNTUA, Ananthapur and working as Assistant Professor of CSE Dept. in CMR College of Engineering and Technology, Hyderabad. Area of research is Big Data, Software Engineering and Data mining. 